\title{
"Domine, labia mea aperies": Forese Donati and Ugolino
}

\author{
Carolynn Lund Mead
}

In the Purgatorio Dante the pilgrim meets penitents such as Forese Donati who are experiencing the fact that, paradoxically, the natural appetites can only be satisfied spiritually. Because inhabitants of hell such as Ugolino lack this experience, Dante's purgatorial encounter with Donati acts as a gloss upon his former meeting with the count. ${ }^{1}$ The subtext which, by means of allusions, joins together the antithetical experiences of Ugolino and of Forese is the Bible, read as a text in which the New Testament is the fulfillment of the Old, in which Christ is the one who fulfills the election of Israel; in which God's redemptive line (as Cullmann designates it) proceeds from the physical realm to the spiritual: from the history of Israel through the history of the Church (the former as "preparation" for the Incarnation, the latter as "expansion," [105]), and culminates in the eschatological future. ${ }^{2}$ While Forese Donati participates in this process of renewal, Ugolino becomes trapped in the present and the physical because he fails to recognize them as stages in an ongoing process.

On the sixth terrace of the purgation of gluttony, Dante meets penitents who, like Ugolino in the Inferno, are suffering from extreme hunger. Amidst singing and weeping Dante hears the words, "Labia mëa, Domine," in a manner that gives birth both to joy and to grief ("per modo / tal, che diletto e doglia parturíe," 23.10-12). The complete phrase from which these words are taken in Psalm 51 (Lat. 50) reads (as is well known), "Domine, labia mea aperies, / Et os meum annuntiabit laudem tuam" (v. 15; Lat. 17). This psalm is described, in The New Oxford Annotated Bible, as a "Prayer for healing and moral renewal (a lament)"; while it is "clear that the psalmist's problem is one of illness" ( $v .8$ ), the emphasis is upon restoration to moral, rather than physical, health (694). Although the penitents who repeat the words of this psalm are physically ema- 
ciated by hunger, their prayer is that their lips may be opened, not that they may eat, but that they may praise God. The words of the psalm, in the King James Version, continue: ${ }^{3}$

For thou desirest not sacrifice; else would I give it: thou delightest not in burnt offering. The sacrifices of God are a broken spirit: a broken and contrite heart, O God, thou wilt not despise. (16-17)

By using their mouths to repeat the verses of this Psalm, the starving penitents bring forth both the "diletto" of praise and the "doglia" of broken and contrite hearts, so that God, having accepted their offerings, will grant them spiritual renewal. In the Inferno Ugolino does not open his mouth either in praise of God or in contrition for his sins; he is silent, his heart turns to stone: "Io non piangëa, sí dentro impetrai" (33.49).

Because his heart solidifies instead of breaking up, Ugolino dooms himself to the banishment with which God punishes the obtuse Israelites in the wilderness, as recorded by the Psalmist and echoed by the Apostle Paul. Both writers warn their contemporaries: "Today if ye will hear his voice, Harden not your heart, as in the provocation, and as in the day of temptation in the wilderness." To the generation who tried his patience for forty years, God swears in his wrath that they shall not enter his rest: "Si introibunt in requiem meam" (Ps. 95 [Lat. 94].8-11; Heb. 3.7-11).

Ugolino is not only denied God's rest, but also forced to live out one of the curses which Moses, on the threshold of the promised land, vows will befall the Israelites if they do not serve God "with joyfulness, and with gladness of heart, for the abundance of all things":

Therefore shalt thou serve thine enemies which the LORD shall send against thee, in hunger, and in thirst, and in nakedness, and in want of all things: and he shall put a yoke of iron upon thy neck, until he have destroyed thee. . . . And thou shalt eat the fruit of thine own body, the flesh of thy sons and of thy daughters, which the LORD thy God hath given thee, in the siege, and in the straitness, wherewith thine enemies shall distress thee. (Deut. 28.47-8, 53)

Ugolino's situation makes allusion to that which the Book of Lamentations describes as occuring during the siege of Jerusalem in 586 B.C.- "Parvuli petierunt panem, / Et non erat qui frangeret eis" (4.4):

Quando fui desto innanzi la dimane, 
pianger senti' fra 'I sonno $i$ miei figliuoli

cheran con meco, e dimandar del pane. (Inf. 33.37-39)

For Ugolino, as for the besieged remnant in Jerusalem, the breaking of bread in imprisonment becomes the act of cannibalism: "The hands of the pitiful women have sodden their own children: they were their meat in the destruction of the daughter of my people" (Lam. 4.10). ${ }^{4}$

When Dante meets the penitents, they are so withered by hunger that Dante exclaims: "Ecco / la gente che perdé Ierusalemme, / quando Maria nel figlio diè di becco!" (Purg. 23.28-30). Maria, during the seige of Jerusalem by Titus in 70 A.D., was driven by hunger to kill and eat her infant son. ${ }^{5}$ Unlike Ugolino and Maria, the souls in purgatory do not submit to their physical cravings; they find spiritual solace in their suffering. Ugolino and Maria open their mouths to consume their offspring whose lives have been sacrificed, only to lose their own lives; the penitents beseech God to open their mouths so that they may bring forth ("parturie") offerings of praise and sacrifices of contrition, which will generate their spiritual rebirth.

Forese Donati, in explaining to Dante the significance of their penance, says:

E non pur una volta, questo spazzo

girando, si rinfresca nostra pena:

io dico pena, e dovria dir sollazzo,

ché quella voglia a li arbore ci mena

che menò Cristo lieto a dire "Eli,"

quando ne liberò con la sua vena. (Purg. 23.70-75)

The famished Forese, who finds "sollazzo" in being led to the inverted tree (the fruits of which he cannot eat), and the dying Christ upon the cross, "lieto a dire 'Eli,'" stand in opposition to Ugolino, who experiences unmitigated anguish when his son Gaddo dies saying, "Padre mio, ché non m'aiuti?" (Inf. 33.69). The words attributed to Christ and to Gaddo allude, of course, to Christ's cry upon the cross, as recorded in the gospels, "Eli, Eli, lama sabachthani? that is to say, My God, my God, why hast thou forsaken me?" (Matt. 27.46 [Mark 15.34]), ${ }^{6}$ words from the opening cry of distress in Psalm 22 (Lat. 21).

The description of the experience of distress in the verses of the psalm which follow this introduction makes use of a metaphor that 
is dramatized in Ugolino's dream:

Quoniam circumdederunt me canes multi;

Erue a framea, Deus, animam meam,

Et de manu canis unicam meam. $(17,21)$

In Ugolino's dream, "cagne magre" pursue an exhausted father and his sons and tear their flanks with sharp teeth (Inf. 33.31-36). Unlike the Psalmist, Ugolino does not pray to God for deliverance, nor is he able to respond to his dream other than with despair. The Psalmist, on the other hand, ends with a cry of triumph, a declaration of faith: "The meek shall eat and be satisfied: they shall praise the Lord that seek him: your heart shall live for ever" (v. 26). Augustine, in his commentary on this psalm, says that these words are "spoken in the person of the Crucified" (144), who declares that those who will eat and be satisfied "shall eat, and imitate Me." They "will neither desire this world's abundance, nor fear its want"; their hearts will live forever because their food is "the food of the heart" (148). Unlike Foresi Donati, who like the Psalmist (and Christ) is able to turn despair into spiritual triumph, Ugolino becomes one of the devouring dogs that he, like the Psalmist, feared: Dante notices that Ugolino's teeth, as he gnaws Ruggieri's head, are strong like a dog's ("come d'un can, forti" [33.78]).

Forese Donati's reference to Christ's cry upon the cross suggests not only that Ugolino could have turned his physical deprivation into spiritual abundance, but also that he could have interiorized and actualized Christ's other words on the cross, "Father, forgive them; for they know not what they do" (Luke 23.34). Instead of ceaselessly gnawing on his enemy Ruggieri's head, "come 'l pan per fame si manduca" (Inf. 32.127), Ugolino could be looking forward with hope to joining the paradisal eucharistic feast: the "sodalizio eletto a la gran cena / del benedetto Agnello, il qual vi ciba / sí, che la vostra voglia è sempre piena" (Par. 24.1-3).

Ugolino in hell is trapped forever in a repetitive re-enactment of a powerful biblical curse which is used to warn the Israelites at liminal periods in their history. It is the curse which Moses warns the Israelites (at the time of their transition to the promised land) will befall them in the future if they become obdurate; it is the curse which Jeremiah and Exekiel ("the two prophets," as Rosenberg states, 
"who most epitomized Israel's transition to exile" [184]) repeat to God's wayward people (Jer. 19.9; Ezek. 5.10); it is the curse which the inhabitants of Jerusalem experience, not only once but for a second time. ${ }^{7}$ In the actualization of this curse, God's chosen people devour their own flesh in God's designated city. This short-circuiting of the birth-death cycle is the final outcome of the self-reflexivity of physical nature without spiritual recourse, of man without God, of a present without an eschatological future.

In response to this impasse, Christ is the one who, as the ultimate contraction of the remnant of Israel, the suffering servant of Second Isaiah, offers himself as sacrifice "for the sin of many" (Isa. 53.12). Christ, "lieto a dire 'Eli,' / quando ne liberò con la sua vena" (Purg. 23.74-75), functions (as Dante learns) both as the mid-point and as the goal of God's redemptive line of history. Not only is Christ the inspiration for Forese Donati's penitential abstinence in purgatory, but in the escatological future he will be the "benedetto Agnello" of "la gran cena," which is (as Moore indicates [374]) "the marriage supper of the Lamb" referred to in Revelation 19.9. The bride at this marriage feast will be "the holy city, new Jerusalem" (Rev. 21.2). As God's redeemed church, Jerusalem will feed spiritually upon her redeemer, "sí, che la vostra voglia è sempre piena." Because the pilgrim Dante traces the steps of the redemptive line from hell to paradise, "prima che morte tempo li prescriba," he is able to "foretaste" ("preliba") that which falls from the table of "la gran cena / del benedetto Agnello" (Par. 24.4-6).

Dante's encounter with Forese Donati glosses his meeting with Ugolino by means of two cross-references: cannabalism during the seiges of Jerusalem, and Christ's despairing cry upon the cross. Ugolino, like Maria before him, hardens his heart and attempts, with tragic results, to requite physical deprivation with physical sustenance; Christ, as the fulfillment of the Psalmist before him and as the model for Forese Donati after him, breaks down in despair and triumphs in assuaging physical extremity with spiritual reassurance. In so doing he opens up this opportunity for all men, not only in the present era of history but in the eternal future.

University of Toronto 


\section{NOTES}

1 From Iannucci comes the the seminal insight of Dante as "il miglior commentatore di se stessso" (306): "La poesia della Commedia è poesia 'critica' in quanto si ripiega continuamente sul proprio significato" (312). Iannucci demonstrates how "Le parole di Oderisi ... servono implicitamente a commentare e precisare il significato di Inferno XV" (109). It is precisely this "episodio parallelo" that destroys Brunetto's notion of immortality. In his initial article, Iannucci expresses the opinion that Dante's Ugolino episode stands without a parallel (327-28). This paper suggests that Forese Donati's relationship to Ugolino demonstrates that the episode of Ugolino, rather than being an exception to Dante's autoesegesi, participates in it.

2 Cullmann describes what he calls "the line of Christ" in redemptive history in the New Testament and other Primitive Christian writings (where it is everywhere presupposed though seldom presented systematically or in chronological sequence) as follows: "Christ the Mediator of the Creation-Christ, God's Suffering Servant as the One who fulfills the election of Israel-Christ the Lord, ruling in the present-Christ the returning Son of Man as the one who completes the entire process and is the Mediator of the new creation" (109).

3 All English renderings of the Bible in this paper are from the King James Version.

4 Although Contini, Shapiro, and Freccero support the view that Ugolino cannibalizes his sons, there are of course dissenting voices. Singleton, for example, considers it a "curious view . . hardly worth a serious rebuttal" (see notes to Inf. 33.75). The wording of Inf. 33.75, which suggests the possibility of cannibalism, and the supporting biblical allusions, which imply such an interpretation, appropriately give shape to a deed which is unspeakable (infandum !).

5 For bibliographical references and Benvenuto's account (in Latin with an English translation) of the story of Mary, see Singleton's notes to Purg. 23.2830.

6 John Freccero expresses the opinion that, "Although critics have not noticed it until recently, the Christological language that is used to describe the children seems the most salient feature of the story" $(56-57 ; 156)$. The particular critics to whom Freccero refers are Contini and Shapiro.

7 Cook and Herzman quote Jer. 19.8-9 (and footnote Isa. 49.26, Ezk. 5.10, and Deut. 28.53) to indicate that, along with several classical sources, the Old Testament "is also a source for the image of cannibalism itself" (379). They demonstrate that "the number of different kinds of sources he is able to use in a complementary way" is one testimony to Dante's richness.

\section{WORKS CITED}

Alighieri, Dante. La Divina Commedia. Ed. Giorgio Petrocchi. 2nd ed. Torino: 
Einaudi, 1975.

Augustine, Saint. Expositions on the Book of Psalms. Vol. I. A Library of Fathers of the Holy Catholic Church. Trans. Members of the English Church. Oxford: Parker, 1847.

Bible. Biblia Sacra iuxta Vulgatam Clementinam. nova editio. 7th ed. Mariti: biblioteca de autores cristianos, 1985.

\section{. The King James Version.}

. The New Oxford Annotated Bible: Revised Standard Version. Eds. Herbert G. May and Bruce M. Metzger. New York: Oxford UP, 1973.

Contini, Gianfranco. "Filologia ed escgesi dantesca." Varianti e altra linguistica: Una raccolta di saggi (1938-1968). Einuadi, 1970. 407-32.

Cook. William R. and Ronald B. Herzman. "Inferno XXXIII: The Past and the Present in Dante's Imagery of Betrayal." Italica 56 (1979): 377-83.

Cullmann, Oscar. Christ and Time. 1946. Trans. Floyd V. Filson. London: SCM Press Lid., 1971.

Freccero, John. "Bestial Sign and Bread of Angels (Inferno 32-33)." Yale Italian Studies 1.1 (1977): 53-66. Rpt. in Dante: the Poetics of Conversion. Ed. Rachel Jacoff. Cambridge: Harvard UP, 1986. 152-166.

Iannucci, Amilcare A. "Autoesegesi dantesca: la tecnica dell' 'episodio parallelo' nella Commedia." Lettere Italiane 33.3 (1981): 305-28. Rev. and rpt. as "Autoesegesi dantesca: la tecnica dell' "episodio parallelo" (Inferno XVPurgatorio XI)." Forma ed evento nella Divina Commedia. Roma: Bulzoni, 1984. 83-114.

Moore, Edward. Studies in Dante; First Series. 1896. New York: Haskell, 1968. Rosenberg, Joel. "Jeremiah and Ezekiel." The Literary Guide to the Bible. Eds. Robert Alter and Frank Kermode. Cambridge: Harvard UP, 1987. 184-206. Shapiro, Marianne. "An Old French Source for Ugolino?" Dante Studies 92 (1974): 129-47.

Singleton, Charles S., trans. The Divine Comedy. 3 vols. Bollingen Series 80 . Princeton: Princeton UP, 1980. 